\title{
Prevalence of virulence genes in Enterococcus species isolated from companion animals and livestock
}

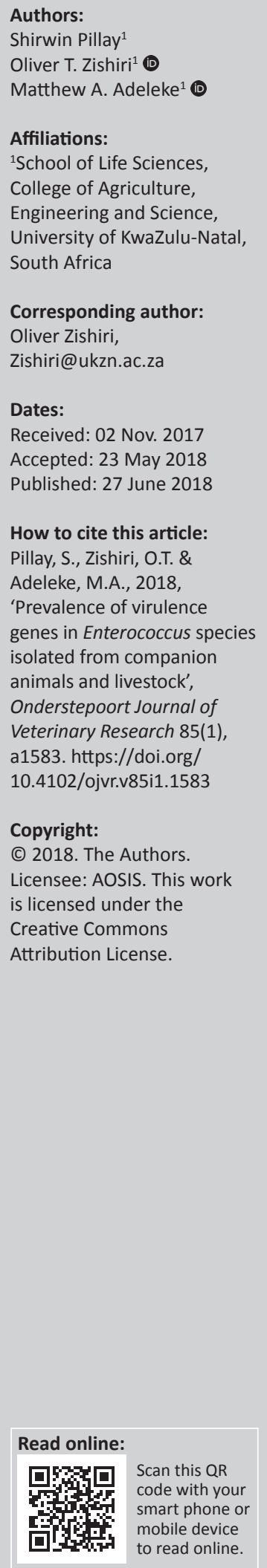

Enterococcus species have developed from being commensal bacteria to leading pathogens that cause infections in humans and animals. The gastrointestinal tract of mammals is the normal habitat of these species. Virulence factors are proteins that are produced by the bacterium which are used to enhance their pathogenicity. The objectives of this study were to isolate Enterococcus spp. from livestock and companion animals, differentiate between the different sub-species and detect the presence of important virulence genes. Rectal and saliva swabs were collected from dogs and cats, whereas only rectal swabs were collected from cattle and cloacal swabs from chickens. Presumptive Enterococcus was selected using Bile Esculin Azide (BEA) agar, and Enterococcus species were confirmed using the polymerase chain reaction (PCR) by amplifying the tuf gene. In order to differentiate between $E$. faecalis and E. faecium, a multiplex PCR was used to detect the SodA gene. The genes responsible for gelatinase production ( $g e l E$ ) and for conjugation ( $c c f)$ were also detected using PCR. Out of 211 animal swabs, $182(86 \%)$ were positive for the $t u f$ gene. Overall, there were 55 isolates of E. faecalis (30\%) compared to 22 isolates of E. faecium (12\%). The virulence genes had a prevalence of $52 \%$ and $36 \%$ for gelE and $c c f$, respectively, in all animal hosts. The results demonstrated that chicken cloacal samples had the highest prevalence for E. faecalis, gelE and $c c f$ genes compared to all the other isolates detected from other animal hosts. The results also demonstrated a statistically significant $(p<0.05)$ association between the prevalence of virulence genes ( $g e l E$ and $c c f$ ) and animal species from which Enterococcus spp. was isolated. We provided evidence that healthy livestock and companion animals can harbour pathogenic Enterococcus that can be transferred via the food chain as well as through close association such as petting and licking of humans. This study partially demonstrated that Enterococci spp. are capable of evolving from being simple commensal bacteria to becoming pathogens that cause infection in humans and animals through the acquisition of virulence factors through mobile genetic elements.

\section{Introduction}

Enterococcus species are a diverse group of Gram-positive, facultative anaerobic bacteria that have a wide adaptability to withstand harsh conditions like temperature, $\mathrm{pH}$, hyperosmolarity and prolonged desiccation (Ali et al. 2014; Lebreton, Willems \& Gilmore 2014; Moraes et al. 2012). Enterococcus species contain the group D cell wall antigen, which is associated with the cytoplasmic membrane. Hence, they were initially classified as Group D Streptococci (Teixeira \& Merquior 2013). Cetinkaya, Falk and Mayhall (2000) reported that Enterococcus was suggested to be a genus on its own and not a part of the Streptococcus genus. This was proposed because of DNA-DNA and DNA-rRNA hybridisation revealing that species such as Streptococcus faecalis (now Enterococcus faecalis) and Streptococcus faecium (now Enterococcus faecium) were relatively distantly related to non-Enterococcal Streptococci. Molecular DNA studies demonstrated that Enterococcus should be classified as its own genus as there are significant differences between Enterococcus and Streptococcus (Byappanahalli et al. 2012). Successful detection of Enterococcus species can be achieved by simply detecting the $t u f$ gene (encoding elongation factor) using the polymerase chain reaction (PCR). The tuf gene encodes the elongation factor EF-Tu and is involved in peptide chain formation. This gene is a highly evolutionarily conserved part of the core genome, and is more discriminative than the 16S rRNA gene for identifying organisms belonging to the Enterococcus genus (Li et al. 2012). In order to differentiate the species of Enterococcus, the SodA gene, which encodes a manganese-dependent superoxide dismutase, can be used. This gene is more discriminative compared to the $16 \mathrm{~S}$ rRNA in differentiating closely related species. Previous studies have shown that fragments of the SodA gene of Enterococcus casselifalvus and Enterococcus flavescens were $99.5 \%$ identical and therefore should be considered the same species (Poyart, Quesnes \& Trieu-cuot 2000). 
The ability of Enterococcus spp. to cause infections has been associated with the species' intrinsic ruggedness (Santagati, Campanile \& Stefani 2012). This trait allows the enterococcal species to persevere in hospital environments and allows the microorganism to withstand a variety of host defences such as the innate immune system. The innate immune defence is an essential first step in combatting infectious disease. To establish infections, pathogens evolved strategies to overcome this defence. Innate immunity consists of the humoral components such as the complement system and cellular components including polymorphonuclear leukocytes, macrophages, mast cells, basophils, eosinophils and dendritic cells. Resistance mechanisms against the innate immune system which enable this commensal organism to become pathogenic are widely unknown. The genetic flexibility of Enterococci is an important feature. They are equipped with many antibiotic resistance and virulence genes that can be attained and transferred (ChajęckaWierzchowska, Zadernowska \& Łaniewska-Trokenheim 2017; Fisher \& Phillips 2009).

Some virulence factors are regulated by virulence coding genes present on plasmids or in specific regions on the genome known as pathogenicity islands (PAI). The PAI contain multiple pathogenicity factors, for example, the enterococcal surface protein (ESP). The ESP is responsible for an increased biofilm formation and colonisation potential. An important virulence factor is an extracellular active gelatinase (GelE). This extracellular zinc-metalloprotease is part of a protection mechanism against the host response (Waters et al. 2003). Gelatinase is essential for resistance to several key components of the host innate immune defence system including antimicrobial peptides preventing damage to the pathogen (Potempa \& Pike 2009). The enzyme causes cleavage and degradation of host proteins like LL-37, fibrinogen, fibrin and collage (Scheb-Wetzel et al. 2014). Comerlato et al. (2013) reported that GelE-positive strains of E. faecalis had an increasing potential to establish a biofilm. These findings underline the importance of GelE for host colonisation and virulence (Scheb-Wetzel et al. 2014).

According to Eaton and Gasson (2001), virulence genes are transferred by a highly efficient transfer mechanism. Species that lack plasmids (recipients) excrete sex pheromones which induce a mating response in Enterococcus that have a certain plasmid (donor), causing an aggregation of recipients and donor cells (Clewell \& Weaver 1989). Hirt et al. (2005) reported that, E. faecalis' sex pheromone plasmids are one of the most efficient conjugative plasmid transfer systems known in bacteria. Sex pheromones in Enterococcus are encoded on the cob, cpd and ccf genes. Studies have demonstrated that Enterococcus strains that possessed and expressed virulence factors caused a more serious infection than strains that lacked virulence factors (ChajęckaWierzchowska et al. 2017). The process of infection involves specific steps such as colonisation, adhesion, tissue invasion and a defence mechanism such as resistance (Flores-Meireles et al. 2015; Upandhyaya, Ravikumar \& Umapathy 2009). It is important to note that in order to be pathogenic, antibiotic resistance genes have to be accompanied by virulence factors and genes (Heidari et al. 2016).

Many Enterococci spp. are mostly associated with the intestines of domestic animals and humans (Wurster, Saavedra \& Gilmore 2016). They play a fundamental role of commensal bacteria found in the microbial consortia in the gut, aiding in the degradation and digestion of food as well as other metabolic pathways (Hammerum 2012; Santagati et al. 2012). Enterococcus faecalis and E. faecium are the most prevalent enterococcal isolates found within the human gastrointestinal tract (Fisher \& Phillips 2009). Enterococcus species' wide adaptability allows the microorganisms to colonise various habitats from hospitals to the human and animal guts and to the natural environment (Lebreton et al. 2014). When these organisms are localised outside the gut, they are considered as faecal pollution indicators. With regard to the human body, they are considered as human pathogens (Santagati et al. 2012). In recent years, there has been substantial progress in the detection of virulence factors in Enterococci of clinical origin. This has therefore made the detection of virulence genes in strains isolated from food possible. Zoonoses are diseases or infections that are transferred from animals to humans and humans to animals either directly or indirectly (WHO 2017). Foodborne zoonoses are a major public health concern worldwide. The African region has the highest incidence and death rates because of these diseases (WHO 2015).

It is therefore important to pay close attention to animals that are closely associated with humans such as companion animals and livestock. Pathogenic bacteria can be transferred through animal saliva, open wounds and contaminated meat from livestock (Schjørring \& Krogfelt 2011). Furthermore, human and companion animal contact because of sharing of common environments will also exacerbate cross transfer of pathogenic bacteria. Once the bacteria are in the intestines of humans, they may colonise and persist or be present for a short time, which may be a sufficient time for virulence and resistance genes to be transferred to other strains, providing them with 'weapons' to cause infections (Nilsson 2012). To our knowledge, there is a paucity of research conducted on the detection and differentiation of Enterococcus species in companion animals and livestock in South Africa, let alone KwaZulu-Natal Province. Against this background, the aim of the study was to investigate the prevalence of Enterococcus spp. in livestock and companion animals in the Durban Metropolitan area. Furthermore, confirmed Enterococcus spp. were differentiated based on the presence of gelE and $c c f$ virulence genes.

\section{Materials and methods Sample collection}

A total of 211 samples (Table 1) were collected, processed and analysed for this study. Sterile swabs were used to randomly collect 70 rectal and mouth swabs from 36 dogs and 34 cats, among those that were treated at a veterinary 
clinic in Durban. The pets that are included in this study live in households in Durban. Seven race horse faecal samples were also included in the study. Thirty-four cattle rectal samples were collected from a herd, and 30 chicken cloacal samples were collected from a chicken farm in Pietermaritzburg (KZN). Samples were collected between October 2016 and February 2017. Upon collection, the swabs were placed in $5 \mathrm{~mL}$ buffered peptone water (BPW) (Merck) for enrichment in $15 \mathrm{~mL}$ centrifuge tubes and transported to the University of KwaZulu-Natal Westville campus for further processing and analyses.

\section{Identification and confirmation of Enterococcus species}

Upon arrival at the laboratory, the samples were incubated at $37^{\circ} \mathrm{C}$ for 24 hours. The samples were further enriched in Trypticase Soy Broth (TSB) by adding $1 \mathrm{~mL}$ of the BPW to $5 \mathrm{~mL}$ TSB and incubated at $37^{\circ} \mathrm{C}$ for $24 \mathrm{~h}$. Bile Esculin Azide (BEA) agar was used to presumptively identify Enterococcus species. A loopful of sample was streaked onto the BEA agar plate and incubated at $37^{\circ} \mathrm{C}$ for $24 \mathrm{~h}$. The detection of Enterococcus species is based on the hydrolysis of esculin in the media into glucose and esculetin. The esculetin reacts with a ferric iron salt to produce a phenolic iron complex, which turns the medium dark brown or black. Bile Esculin Azide agar contains ingredients such as bile salts and sodium azide to inhibit the growth of other Gram-positive and Gram-negative organisms, respectively. Single colonies that turned the media black were selected and were added to $5 \mathrm{~mL}$ of TSB. This was incubated as previously described for DNA extraction and PCR. Deoxyribonucleic acid extraction was performed according to Ruiz-barba, Maldonado and Jiménez-díaz (2005). The concentration and quality of the isolated DNA were checked with the use of the Thermo-

TABLE 1: Distribution of samples based on animal species and site of swab collection.

\begin{tabular}{llc}
\hline Animal species & Site of swab collection & Number of animals sampled \\
\hline Dogs & Rectal & 36 \\
& Mouth & 36 \\
Cats & Rectal & 34 \\
& Mouth & 34 \\
Cattle & Rectal & 34 \\
Chickens & Cloacal & 30 \\
Horses & Faecal & 7 \\
\hline
\end{tabular}

Scientific Nanodrop 2000, UV-VIS Spectrophotometer (Wilmington, Delaware, USA). A $25.0 \mu \mathrm{L}$ PCR was used to amplify the tuf gene (112 bp) in order to confirm enterococcal species using primers (Table 2). The reaction mixture contained $12.5 \mu \mathrm{L}$ Thermo-Scientific master mix, 1 pmol (1.0 $\mu \mathrm{L}$ of $10.0 \mu \mathrm{M}$ ) of each primer, $5.5 \mu \mathrm{L}$ of sterile $\mathrm{H}_{2} \mathrm{O}$ and $5.0 \mu \mathrm{L}$ of extracted DNA. As positive and negative controls, known DNA from E. faecalis and sterile water were used, respectively. The thermocycler conditions were as follows: initial denaturation at $94{ }^{\circ} \mathrm{C}$ for $4 \mathrm{~min}$ followed by 34 cycles of denaturation at $94^{\circ} \mathrm{C}$ for $1 \mathrm{~min}$, annealing at $53^{\circ} \mathrm{C}$ for $1 \mathrm{~min}$, extension at $72{ }^{\circ} \mathrm{C}$ for $1 \mathrm{~min}$ followed by the final extension at $72{ }^{\circ} \mathrm{C}$ for $5 \mathrm{~min}$. Thereafter, the PCR products were subjected to gel electrophoresis using a 1.5\% agarose gel stained with $10 \mathrm{mg} / \mathrm{mL}$ ethidium bromide for $40 \mathrm{~min}$ at $80 \mathrm{~V}$. A $100 \mathrm{bp}$ ladder was used to determine the size of the product amplified. Products were visualised under UV light in the BIO-RAD, ChemiDoc ${ }^{\mathrm{TM}}$ MP Imaging System.

\section{Identification of $E$. faecalis and $E$. faecium}

A $25.0 \mu \mathrm{L}$ multiplex PCR was used to detect the sodA gene in positive Enterococcus species. The primer sequence (Table 2) used to detect the sodA gene, of $210 \mathrm{bp}$ and $360 \mathrm{bp}$ for E. faecalis and E. faecium, respectively, is depicted in Table 2. The reaction mixture contained $12.5 \mu \mathrm{L}$ of the $10 \mathrm{X}$ master mix, $4.5 \mu \mathrm{L}$ of sterile water, 1 pmol of each primer and $4.0 \mu \mathrm{L}$ of the extracted DNA. Four microliters $(4.0 \mu \mathrm{L})$ of known DNA was used as a positive control and $4.0 \mu \mathrm{L}$ of sterile water was used as a negative control. The thermocycler conditions were as follows: initial denaturation at $95^{\circ} \mathrm{C}$ for $3 \mathrm{~min}$, followed by 34 cycles of denaturation of $95{ }^{\circ} \mathrm{C}$ for $30 \mathrm{~s}$, two annealing steps at $48{ }^{\circ} \mathrm{C}$ and $55^{\circ} \mathrm{C}$ for $30 \mathrm{~s}$ each, extension at $72{ }^{\circ} \mathrm{C}$ for $1 \mathrm{~min}$ and a final extension step at $72{ }^{\circ} \mathrm{C}$ for $7 \mathrm{~min}$. To visualise PCR products, electrophoresis was run for $60 \mathrm{~min}$ at $80 \mathrm{~V}$ using a $1.5 \%$ agarose gel which was stained with $10 \mathrm{mg} / \mathrm{mL}$ ethidium bromide. The size of PCR products was visualised under UV light in the BIO-RAD, ChemiDoc ${ }^{\mathrm{TM}} \mathrm{MP}$ Imaging System.

\section{Detection of gelE and $c c f$ virulence genes}

The gelE and the $c c f$ genes were amplified using PCR in a $25.0 \mu \mathrm{L}$ reaction, using previously described primers as indicated in Table 2. A $25.0 \mu \mathrm{L}$ reaction was used for each gene. The reaction mixture contained $12.5 \mu \mathrm{L}$ of the $10 \mathrm{X}$

TABLE 2: Target genes, oligonucleotide primer sequences, amplicon sizes and annealing temperatures used for the detection of Enterococcus faecalis and Enterococcus faecium.

\begin{tabular}{|c|c|c|c|c|c|}
\hline Gene & Primer & Sequence & Product size & $\mathrm{Ta}\left({ }^{\circ} \mathrm{C}\right)$ & Reference \\
\hline \multirow[t]{2}{*}{ tuf } & Forward & 5'-TACTGACAAACCATTCATGATG-3' & 112 bp & 53 & (Ke et al. 1999) \\
\hline & Reverse & 5'-AACTTCGTCACCAACGCGAAC-3' & & & \\
\hline \multirow[t]{2}{*}{ SodA - E. faecalis } & Forward & 5'-ACTTATGTGACTAACTTAACC-3' & $360 \mathrm{bp}$ & 55 & (Jackson, Fedorka-Cray \& Barrett 2004) \\
\hline & Reverse & 5'-TAATGGTGAATCTTGGTTTGG-3' & & & \\
\hline \multirow[t]{2}{*}{ SodA - E. faecium } & Forward & 5'-GAAAAAACAATAGAAGAATTAT-3' & $215 \mathrm{bp}$ & 48 & (Jackson et al. 2004) \\
\hline & Reverse & 5'-TGCTTTTTTGAATTCTTCTTTA-3' & & & \\
\hline \multirow[t]{2}{*}{ gelE } & Forward & 5'-ACC CCG TAT CAT TGG TTT-3' & $419 \mathrm{bp}$ & 55 & (Eaton \& Gasson 2001) \\
\hline & Reverse & 5'-ACG CAT TGC TTT TCC ATC-3' & & & \\
\hline \multirow[t]{2}{*}{$c c f$} & Forward & 5'-GGG AAT TGA GTA GTG AAG AAG-3' & 543 bp & 52.5 & (Eaton \& Gasson 2001) \\
\hline & Reverse & 5'-AGC CGC TAA AAT CGG TAA AAT-3' & & & \\
\hline
\end{tabular}

Ta, annealing temperature. 
master mix by Thermo-Scientific, $5.5 \mu \mathrm{L}$ of sterile water, 1 pmol of each primer (Table 2) and $5.0 \mu \mathrm{L}$ of the extracted DNA. For negative control PCR, $5.0 \mu \mathrm{L}$ of sterile water was used. The thermocycler conditions were as follows for amplification of the gelE gene: 34 cycles of denaturation of $94.0{ }^{\circ} \mathrm{C}$ for $1 \mathrm{~min}$, annealing steps at $50.0{ }^{\circ} \mathrm{C}$ for $1 \mathrm{~min}$, extension at $72.0^{\circ} \mathrm{C}$ for $1 \mathrm{~min}$ and a final extension step at $72.0{ }^{\circ} \mathrm{C}$ for $10 \mathrm{~min}$. For amplification of the ccf gene, the conditions were initial denaturation at $94.0{ }^{\circ} \mathrm{C}$ for $4 \mathrm{~min}$ followed by 35 cycles of denaturation at $94.0^{\circ} \mathrm{C}$ for $1 \mathrm{~min}$, annealing at $51.3^{\circ} \mathrm{C}$ for $1 \mathrm{~min}$, extension at $72.0^{\circ} \mathrm{C}$ for $1 \mathrm{~min}$ followed by the final extension at $72.0^{\circ} \mathrm{C}$ for $5 \mathrm{~min}$.

PCR products were subjected to gel electrophoresis using a $1.5 \%$ agarose gel for $40 \mathrm{~min}$ at $80 \mathrm{~V}$ which was stained with $10 \mathrm{mg} / \mathrm{mL}$ ethidium bromide. A $100 \mathrm{bp}$ ladder was used to determine the size of the product amplified. Products were visualised under UV light in the BIO-RAD, ChemiDoc ${ }^{\mathrm{TM}}$ MP Imaging System.

\section{Statistical analysis}

Genes for species identification and virulence were statistically analysed using IBM SPSS statistics (version 24). Chi-square tests were used to test the significance of the prevalence of genes detected from the different sites and species of animals. A binary logistic regression analysis was applied to evaluate the relationship between genes detected in companion animals and livestock. The model included the presence and absence of each gene used to detect species and virulence factor. The data were coded as 1 or 0 if the gene was present or absent, respectively. Associations were considered significant when $p<0.05$.

\section{Ethical considerations}

Animal studies have been approved by the appropriate ethics committee of the University of KwaZulu-Natal (Reference: AREC/040/016M); therefore, they have been performed in accordance with the ethical standards laid down in the 1964 Declaration of Helsinki and its later amendments.

\section{Results}

The gel image shown in Figure 1 represents the target genes that were amplified in this study.

Out of a total of 211 animal swabs examined to detect the presence of Enterococcus species, 86\% (182) of the samples were positive for the tuf gene.

The results in Figure $2 \mathrm{a}$ and $\mathrm{b}$ depict the prevalence of the E. faecalis and E. faecium and other Enterococcus spp. in each animal species and the site of isolation, respectively. Enterococcus faecalis was mostly present in chicken cloacal samples (80\%), while cattle rectal samples had no incidence of E. faecalis or E. faecium. Figure $2 \mathrm{~b}$ shows that rectal and cloacal samples have a higher incidence of $E$. faecalis compared to E. faecium. Overall, there was a higher prevalence of undifferentiated Enterococcus spp.

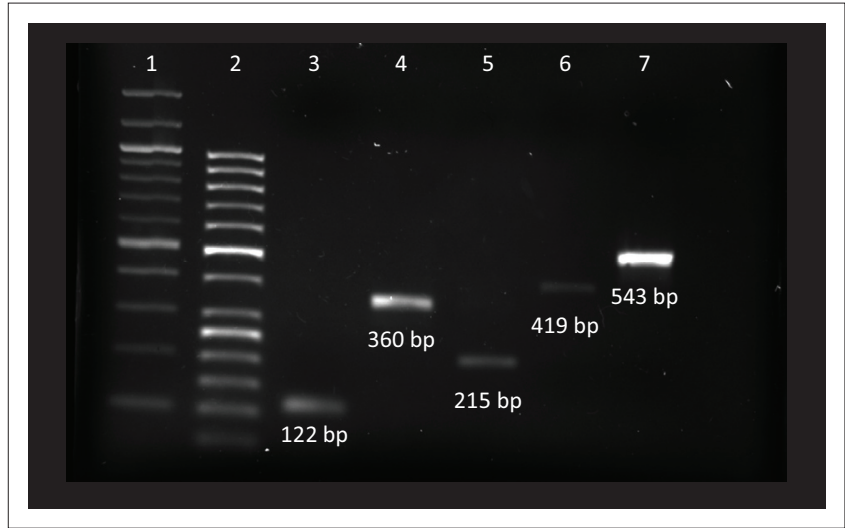

bp, base pair.

FIGURE 1: Represents the successful genomic DNA amplification of the tuf gene (112 bp), from dog rectal sample 6 in lane 3, SodA gene for Enterococcus faecalis from dog saliva sample 25 (360 bp) and Enterococcus faecium from chicken cloacal sample 20 (215 bp) in lane 4 and lane 5, respectively, gelE (419 bp) in lane 6 and the $c c f$ gene ( $543 \mathrm{bp}$ ) in lane 7 from chicken cloacal sample 10. Lane 1 and lane 2 are $100 \mathrm{bp}$ and $50 \mathrm{bp}$ molecular weight markers, respectively.

The prevalence of the virulence genes, gelE and $c c f$, in each animal species and the site of isolation, respectively, is shown in Figure $3 a$ and $b$, respectively. Chicken samples had the highest incidence of virulence genes, while there was no incidence of the two virulence genes in cattle samples. Dogs had the second highest prevalence of gelE gene, while cats were next to chickens with respect to the prevalence of $c c f$ gene. Figure $3 b$ shows that gelE was common in saliva of the animals, while the $c c f$ gene was commonly found in rectal samples. The Enterococcus species and virulence genes present on each site of swab collection from dogs and cats are presented in Figure 4.

Figure 5 indicates that E. faecalis, E. faecium and the two virulence genes were not detected in the cattle rectal samples. However, there was a high incidence of E. faecalis, gelE and the $c c f$ gene in the chicken rectal samples.

Figure 6 indicates that E. faecalis had a higher incidence than E. faecium and the unknown enterococcal species as per this study. Figure 6 also indicates that there was a higher prevalence of E. faecalis of the two species. Enterococcus faecalis had a higher prevalence of both the $c c f$ gene and the gelE gene. Therefore, in this study, E. faecalis was the more common potentially pathogenic species.

Results of chi-square test, likelihood ratio and Fischer's exact test for species-specific and virulence genes are presented in Table 3 . The prevalence of $E$. faecalis from source was statistically significant $(p<0.05)$ compared to E. faecium which was statistically insignificant $(p>0.05)$. Both virulence genes were very highly significant $(p<0.001)$ from the source. With regard to the site of sampling, genes used to identify species and for virulence were statically insignificant $(p>0.05)$.

The logistic regression analysis represented in Table 4 was statistically insignificant $(p>0.05)$ for all the genes except for $E$. faecium and the gelatinase gene ( $\mathrm{gelE}$ ) in animal species. $B$ represents the regression coefficient and defines the rate of 


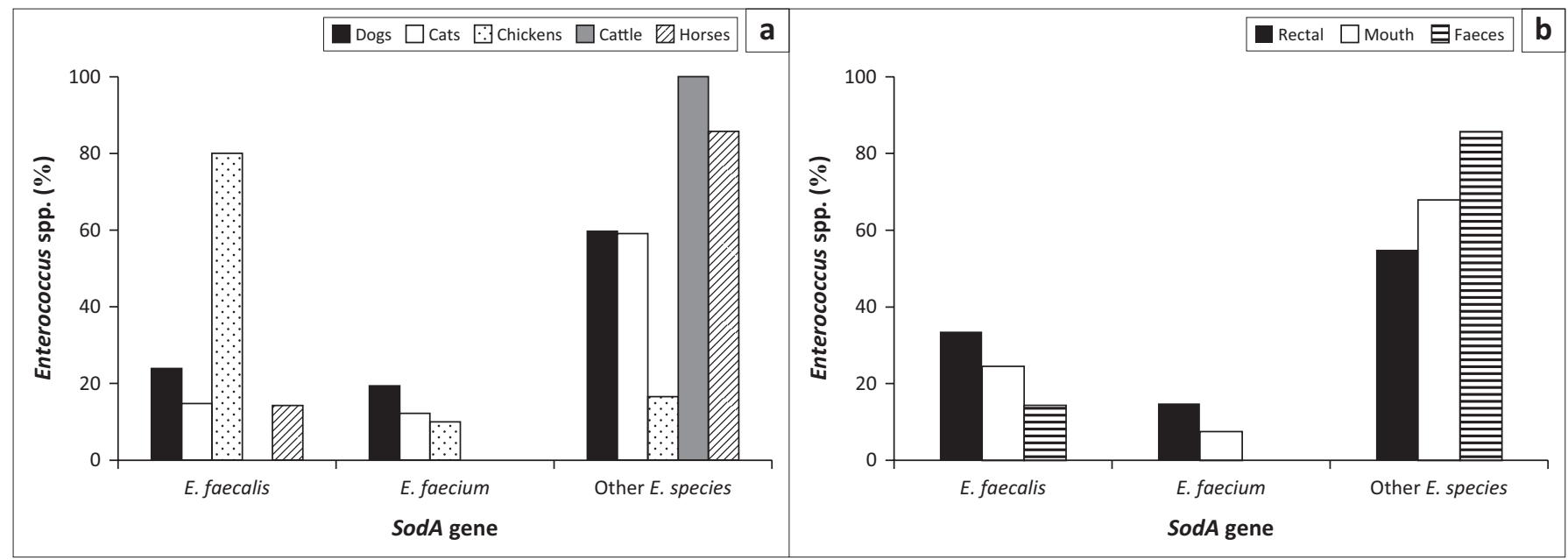

FIGURE 2: (a) Species within animal sources and (b) species within site of collection - prevalence of Enterococcus spp. detected in each animal species and within each site of collection.

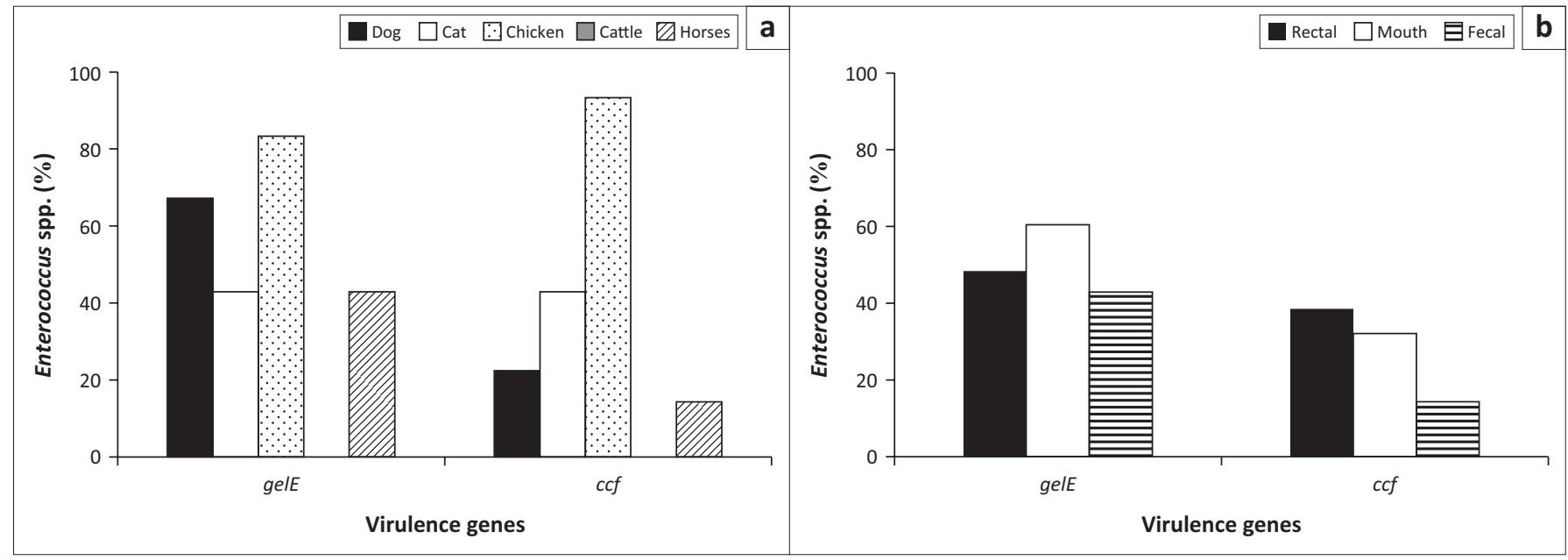

FIGURE 3: (a) Virulence genes within animal species and (b) virulence genes within site of collection - prevalence of virulence genes detected in each animal species and within each site of collection.

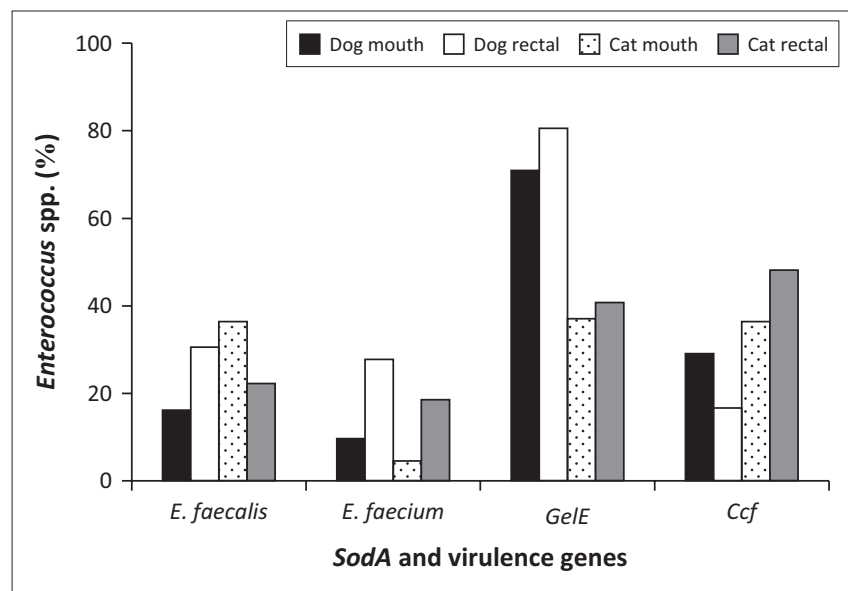

FIGURE 4: Prevalence of Enterococcus faecalis, Enterococcus faecium and virulence genes gelE and $c c f$ in companion animals.

change of one variable as a function of changes in the other. It is also the slope of the regression line. Taking the exponential of $B$ produced $\operatorname{Exp}(B)$, also known as odds ratio, which determines whether there is association between the categorical variables and sources of variation tested at $95 \%$ confidence interval.

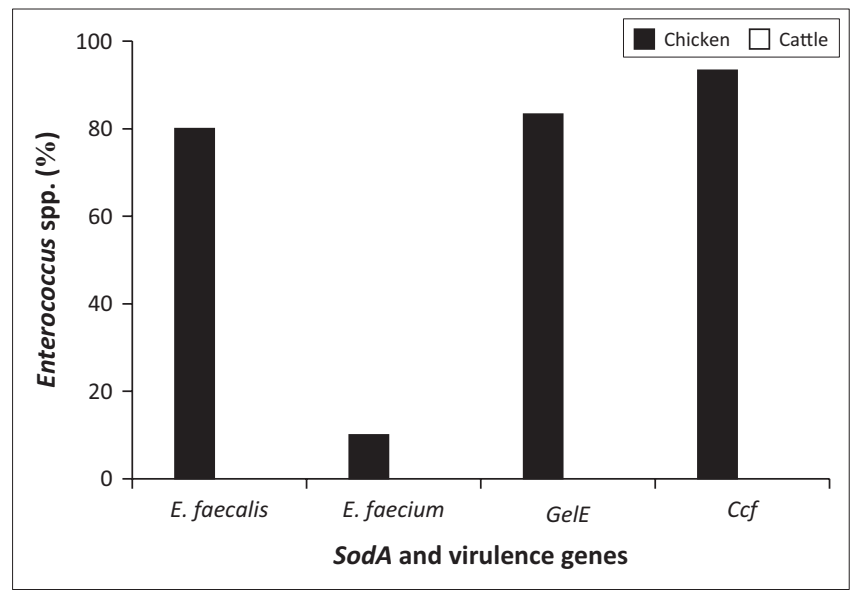

FIGURE 5: Prevalence of Enterococcus faecalis, Enterococcus faecium and virulence genes gelE and $c c f$ in livestock.

\section{Discussion}

Animal faeces that contains virulent Enterococcus species poses a major public health threat. These bacterial strains can be transmitted to closely related humans through the eating of contaminated food which allows the spread and perseverance 


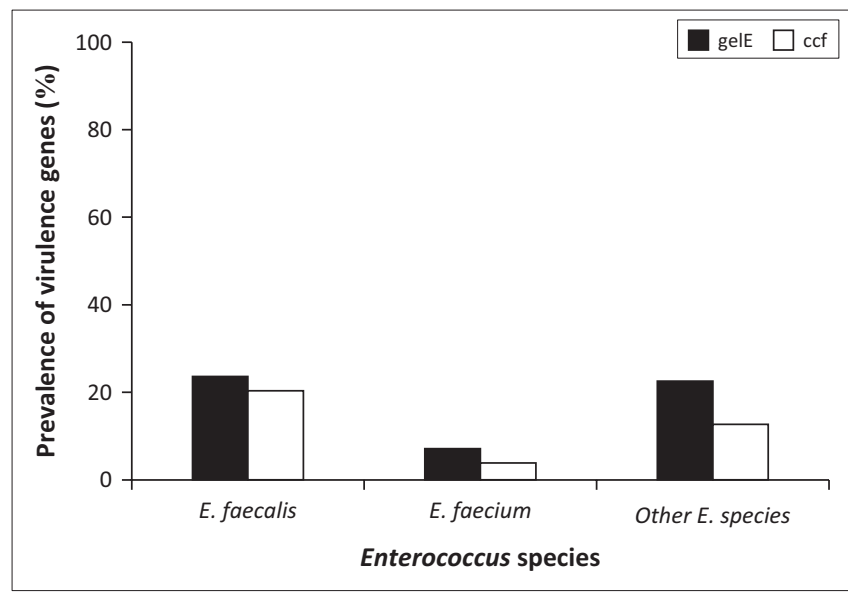

FIGURE 6: Prevalence of each virulence gene detected within each Enterococcal species.

TABLE 3: Chi-square test, likelihood ratio and Fischer's exact test for target Enterococcus spp. and virulence genes.

\begin{tabular}{llcccc}
\hline Source of variation & Statistical test & E. faecalis & E. faecium & gelE & ccf \\
\hline Animal species & Chi-square test & 0.001 & 0.076 & 0.001 & 0.001 \\
& Likelihood ratio & 0.001 & 0.015 & 0.001 & 0.001 \\
& Fischer's exact test & 0.001 & 0.067 & 0.001 & 0.001 \\
Site of swab & Chi-square test & 0.313 & 0.246 & 0.307 & 0.346 \\
collection & Likelihood ratio & 0.291 & 0.154 & 0.305 & 0.310 \\
& Fischer's exact test & 0.404 & 0.374 & 0.302 & 0.392 \\
\hline
\end{tabular}

TABLE 4: Null model output from binary logistic regression showing association of virulence genes detected in Enterococcus spp. between companion animals and livestock.

\begin{tabular}{llcccccc}
\hline $\begin{array}{l}\text { Species } \\
\text { or gene }\end{array}$ & $\begin{array}{l}\text { Source of } \\
\text { variation }\end{array}$ & B & SE & $p$ & Exp(B) & \multicolumn{2}{c}{$95 \%$ Cl for EXP(B) } \\
\hline \multirow{2}{*}{ E. faecalis } & Animal species & -0.049 & 0.140 & 0.725 & 0.952 & 0.724 & 1.253 \\
& Site & -0.492 & 0.324 & 0.128 & 0.611 & 0.324 & 1.152 \\
\multirow{2}{*}{ E. faecium } & Animal species & -0.872 & 0.281 & 0.002 & 0.418 & 0.241 & 0.725 \\
& Site & -1.383 & 0.600 & 0.021 & 0.251 & 0.077 & 0.813 \\
\multirow{2}{*}{ gelE } & Animal species & -0.515 & 0.134 & 0.001 & 0.597 & 0.460 & 0.776 \\
& Site & 0.208 & 0.287 & 0.468 & 1.231 & 0.702 & 2.161 \\
\multirow{2}{*}{ ccf } & Animal species & 0.006 & 0.131 & 0.964 & 1.006 & 0.778 & 1.301 \\
& Site & -0.400 & 0.295 & 0.176 & 0.671 & 0.376 & 1.196 \\
\hline
\end{tabular}

Site, site of swab collection; B, parameter estimates (log-odds) known as coefficient for the constant in the null model. $\mathrm{SE}$, standard error around the parameter estimates; $p=$ probability indicating love of rignificance; $\operatorname{Exp}(\mathrm{B})$, exponential of $\mathrm{B}$ (also called 'odds rati') for the independent variable Xi; $95 \% \mathrm{Cl}, 95 \%$ confidence interval.

of bacteria in the general population and environment (Daniel et al. 2015). In this study, we evaluated Enterococcus species isolated from companion animals and livestock as well as the presence of virulence genes. A high incidence of Enterococcus species was observed (86\%). This is in concordance with several studies from around the world as Enterococcus species are commensal organisms that inhabit the gastrointestinal tract of animals. Enterococci spp. have been previously reported in high incidence in several reports from South Africa (Iweriebor, Obi \& Okoh 2015), Tunisia (Said et al. 2017), China (Liu et al. 2012), Nigeria (Anyanwu \& Obetta 2015), Korea (Bang et al. 2017; Kwon et al. 2012), Turkey (Gökmen et al. 2017) and Australia (Barlow et al. 2017). Comparative studies are currently not feasible because there is a paucity of similar studies on Enterococcus species from livestock animals and companion animals under South African conditions. However, Iweriebor et al. (2015) reported the detection of Enterococcus species as well as the gelatinase gene in piggeries in the Eastern Cape Province of South Africa and concluded that Enterococcus spp. from pigs must be treated with the highest caution because they may be reservoirs for virulence and antibiotic resistance genes. Molale and Bezuidenhout (2016) provided evidence on the virulence determinants in Enterococcus spp. from surface water systems in South Africa. These sources can allow the spread of resistance and virulent bacteria (Carvalho et al. 2014). When Enterococci isolates were analysed by species, E. faecalis was found overall to be the prevalent species. The results from this study were similar to studies, where E. faecalis was reported the most prevalent species (Yildiz \& Turkyilmaz 2015).

In chickens, E. faecalis (80\%) was highly present compared to E. faecium (10\%). Aslam et al. (2012) reported a similar result where overall E. faecalis was the most commonly identified species. Yilmaz et al. (2016) reported that chicken meat samples harboured a higher incidence of E. faecalis (98\%) than E. faecium ( 1\%). However, a study conducted in Nigeria by Ngbede et al. (2017) showed that E. faecium was the predominant (49\%) species in chicken faeces. A similar result was also observed by Ali et al. (2014) and Ünal, Aşkar and Yildirim (2017), with a prevalence of $66.0 \%$ and $33.6 \%$, respectively. In these studies, E. faecalis was the second most prevalent species in chicken samples.

The reason as to why we did not detect E. faecalis and $E$. faecium in cattle as well the virulence genes is unclear as this was not observed in other studies. Yilmaz et al. (2016) detected a high prevalence of E. faecalis (100\%) in beef samples. Barlow et al. (2017) detected 6.4\% and 8.0\% for E. faecalis and E. faecium in the order listed from cattle faecal samples. Seputienè et al. (2012) showed that E. faecium strains did not carry the gelE gene but only E. faecalis. Ngbede et al. (2017) showed that $23.8 \%$ of cattle rectal species were positive for the gelE gene. However, Aslam et al. (2012) reported that E. hirae was a predominant species in beef samples. The lack of virulence genes from healthy animals therefore requires further investigation.

Molecular screening of genes which encode virulence factors revealed that the sex pheromone gene, ccf, was prevalent in E. faecium. According to Eaton and Gasson (2001), the sex pheromone genes, $c c f$, as well as $c o b$ and $c b p$ were not detected in E. faecium strains. The incidence of the gelE gene was the most predominant virulence factor. As previously alluded, the gelE gene encodes the gelatinase enzyme that is responsible for the hydrolysis of haemoglobin, collagen, casein, insulin, fibrinogen, gelatin and other proteins (Upandhyaya et al. 2009). Regardless of the fact that the gelE gene was highly prevalent, it is not indicative of the production of gelatinase. It has been suggested that there are other genes which are associated with the expression of gelatinase (Lindenstrauß et al. 2011).

People who have close relationships with household pets produce conditions for bacteria to be transferred to and from 
their pets through licking, petting, feeding and cleaning. This is a potential threat to the health of human beings if thorough personal hygiene and routine animal and home disinfection is not practised. Enterococcus faecalis was the most prevalent Enterococcus species in dogs and E. faecium was the most prevalent species in cats. Issepi et al. (2015) reported that E. faecium and E. faecalis were the most frequently isolated species from faeces of dogs and cats. It was also reported that strains of Enterococcus had a high incidence of the gelatinase gene as evidenced in our study. Kataoka et al. (2014) and Ossiprandi and Zerbini (2015) reported similar results whereby E. faecalis was most prevalent in dogs. Iseppi et al. (2015) explained that we should not exclude the possibility that Enterococcus strains had silent virulence genes as well and that it is known that environmental signals can play a vital role in gene expression, hence influencing pathogenicity. According to Kataoka et al. (2014), animals are generally not affected by enterococcal infections; however, they act as a reservoir for pathogenic strains. Therefore, the detection of virulence factors of Enterococci in animals is crucial.

There is a statistically significant $(p<0.05)$ relationship among E. faecalis detected from the different animal species used in this study. This indicates that the E. faecalis detected are dependent on animal species. For the virulence genes ( $g e l E$ and $c c f$ ) identified in the animal species, their prevalence depends on each other because the probability for the chisquare is very highly significant showing a statistically significant $(p<0.05)$ association between the occurrence and the absence of gelE and $c c f$. Non-significance $(p>0.05)$ of virulence genes shows that occurrence of these genes is completely independent of site of sampling. Furthermore, the probability of detecting E. faecalis, gelE and $c c f$ in different animal species sampled is $0.1 \%$. The probability of odds for detecting E. faecium decreased by $58.2 \%$ and $74.9 \%$ in animal species and site of swab collection, respectively, while that of gelE would drop by $40.3 \%$.

\section{Conclusion}

Our study detected the prevalence of the two most important enterococcal species (E. faecalis and E. faecium) from companion animals and livestock. We also detected virulence genes encoding gelatinase and a pheromone that induces conjugation, that is, gelE and $c c f$, respectively. In addition, the results also indicated that there was a strong association between the prevalence of virulence genes and animal species. A strong relationship also exists between the occurrence of $E$. faecalis and animal species. Our study has demonstrated that pets can be considered as a reservoir of potentially pathogenic Enterococci endowed with antimicrobial resistance and virulence factors. Therefore, we cannot exclude the possibility that Enterococci isolated from dogs and cats may be responsible for opportunistic infections in humans, particularly among high-risk owners. More studies should be conducted in order to investigate the prevalence of pathogenic Enterococcus spp. from cattle and horses because this study did not detect the two species, and a small sample size was used.

\section{Acknowledgements}

The authors would like to thank the College of Agriculture, Engineering and Science as well as the School of Life Sciences at University of KwaZulu-Natal (Westville campus) for financial support. The National Research Foundation is also sincerely acknowledged for providing a bursary for the first author in order to undertake this study. The authors also thank the anonymous (for confidentiality reasons) veterinary surgeries and farmers in the Durban Metropolitan areas who provided the samples for this study.

\section{Competing interests}

There is no conflict of interest from any of the parties involved in this publication and all parties gave their consent to publish this work.

\section{Authors' contributions}

S.P. was responsible for sample collection, the greater part of the laboratory work and writing up of the manuscript. O.T.Z. conceived the idea, supervised the sample collection and lab work, did the greatest part of the statistical analysis and contributed to the writing of the manuscript. M.A.A. supervised sampling and lab work, assisted with the statistical analysis and wrote parts of the manuscript.

\section{References}

Ali, S.A., Hasan, K.A., Bin Asif, H. \& Abbasi, A., 2014, 'Environmental enterococci: I. Prevalence of virulence, antibiotic resistance and species distribution in poultry and its related environment in Karachi, Pakistan', Letters in Applied Microbiology 58(5), 423-432. https://doi.org/10.1111/lam.12208

Anyanwu, M.U. \& Obetta, T.U., 2015, 'Prevalence and antibiogram of generic enterococci in ready-to-slaughter beef cattle', Notulae Scientia Biologicae 7(4), 390-399. https://doi.org/10.15835/nsb.7.4.9681

Aslam, M., Diarra, M.S., Checkley, S., Bohaychuk, V. \& Masson, L., 2012 'Characterization of antimicrobial resistance and virulence genes in Enterococcus spp. isolated from retail meats in Alberta, Canada', International Journal of Food Microbiology 156, 222-230. https://doi.org/10.1016/j.ijfoodmicro.2012.03.026

Bang, K., An, J.-U., Kim, W., Dong, H.-J., Kim, J. \& Cho, S., 2017, 'Antibiotic resistance patterns and genetic relatedness of Enterococcus faecalis isolated from military working dogs in Korea', Journal of Veterinary Science 18(2), 229-236. https://doi. org/10.4142/jvs.2017.18.2.229

Barlow, R.S., McMillan, K.E., Duffy, L.L., Fegan, N., Jordan, D. \& Mellor, G.E., 2017 'Antimicrobial resistance status of Enterococcus from Australian cattle populations at slaughter', PLoS One 12(5), 1-13. https://doi.org/10.1371/journal.pone.0177728

Byappanahalli, M.N., Nevers, M.B., Korajkic, A., Staley, Z.R. \& Harwood, V.J., 2012, 'Enterococci in the Environment', Microbiology and Molecular Biology Reviews 76(4), 685-706. https://doi.org/10.1128/MMBR.00023-12

Carvalho, E.M.R., Costa, R., Arajo, A.J.G., Carvalho, F.C.T., Pereira, S.P., Sousa, O.V et al., 2014, 'Multiple antibiotic-resistance of Enterococcus isolated from coastal water near an outfall in Brazil', African Journal of Microbiology Research 8(17), 1825-1831. https://doi.org/10.5897/AJMR2014.6672

Cetinkaya, Y., Falk, P. \& Mayhall, C.G., 2000, 'Vancomycin-resistant enterococci', Clinical Microbiology Reviews 13(4), 686-707. https://doi.org/10.1128/CMR.13.4.686707.2000

Chajęcka-Wierzchowska, W., Zadernowska, A. \& Łaniewska-Trokenheim, Ł., 2017 'Virulence factors of Enterococcus spp. presented in food', LWT - Food Science and Technology 75, 670-676. https://doi.org/10.1016/j.lwt.2016.10.026

Clewell, D. \& Weaver, K., 1989, 'Sex pheromones and plasmid transfer in Enterococcus faecalis', Plasmid 21(3), 175-184. https://doi.org/10.1016/0147-619X(89)90041-3

Comerlato, C.B., de Resende, M.C.C., Caierão, J. \& d’Azevedo, P.A., 2013, 'Presence of virulence factors in Enterococcus faecalis and Enterococcus faecium susceptible and resistant to vancomycin', Memorias Do Instituto Oswaldo Cruz 108(5), 590595. https://doi.org/10.1590/0074-0276108052013009

Daniel, D.S., Lee, S.M., Dykes, G.A. \& Rahman, S., 2015, 'Public health risks of multipledrug-resistant Enterococcus spp. in Southeast Asia', Applied and Environmental Microbiology 81(18), 6090-6097. https://doi.org/10.1128/AEM.01741-15

Eaton, T.J. \& Gasson, M.J., 2001, 'Molecular screening of Enterococcus virulence determinants and potential for genetic exchange between food and medical isolates', Applied and Environmental Microbiology 67(4), 1682-1635. https://doi. org/10.1128/AEM.67.4.1628 
Fisher, K. \& Phillips, C., 2009, 'The ecology, epidemiology and virulence of Enterococcus', Microbiology 155(6), 1749-1757. https://doi.org/10.1099/mic.0.026385-0

Flores-Meireles, A., Walker, J., Caparon, M. \& Hultgren, S., 2015, 'Urinary tract infections: Epidemiology, mechanisms of infection and treatment options', Nature Reviews Microbiology 13(5), 269-284. https://doi.org/10.1038/nrmicro3432.Urinary

Gökmen, M., Önen, A., Ektik, N., Kara, R., Torlak, E. \& Metli, M., 2017, 'Detection of prevalence, antibiotic resistance and virulence factors of Enterococcus spp. Isolate from ready to eat foods', Kocatepe Veterinary Journal 10(2), 76-82. https://doi. org/10.5578/kvj.54067

Hammerum, A.M., 2012, 'Enterococci of animal origin and their significance for public health', Clinical Microbiology and Infection 18(7), 619-625. https://doi.org/10.1111/ j.1469-0691.2012.03829.x

Heidari, H., Emaneini, M., Dabiri, H. \& Jabalameli, F., 2016, 'Virulence factors, antimicrobial resistance pattern and molecular analysis of Enterococcal strains isolated from burn patients', Microbial Pathogenesis 90, 93-97. https://doi.org/ 10.1016/j.micpath.2015.11.017

Hirt, H., Manias, D.A., Bryan, E.M., Klein, J.R., Marklund, J.K., Staddon, J.H. et al., 2005 'Characterization of the pheromone response of the Enterococcus faecalis conjugative plasmid pCF10: Complete sequence and comparative analysis of the
transcriptional and phenotypic responses of pCF10-Containing cells to pheromone induction', Journal of Bacteriology 187(3), 1044-1054. https://doi.org/10.1128/ JB.187.3.1044

Iseppi, R., Messi, P., Anacarso, I., Bondi, M., Sabia, C., Condò, C. \& de Niederhausern, S., 2015, 'Antimicrobial resistance and virulence traits in Enterococcus strain isolated from dogs and cats', New Microbiologica 38, 369-378.

Iweriebor, B.C., Obi, L.C. \& Okoh, A.I., 2015, 'Virulence and antimicrobial resistance factors of Enterococcus spp. isolated from fecal samples from piggery farms in Eastern Cape, South

Jackson, C.R., Fedorka-Cray, P.J. \& Barrett, J.B., 2004, 'Use of a genus- and speciesspecific multiplex PCR for identification of enterococci use of a genus- and species-Specific multiplex PCR for identification of enterococci', Journal of Clinical Microbiology 42(8), 3558. https://doi.org/10.1128/JCM.42.8.3558

Kataoka, Y., Umino, Y., Ochi, H., Harada, K. \& Sawada, T., 2014, 'Antimicrobial susceptibility of Enterococcal species isolated from antibiotic-treated dogs and cats', Journal of Veterinary Medical Science https://doi.org/10.1292/jvms.13-0576

Ke, D., Picard, F.J., Martineau, F., Menard, C., Roy, P.H., Ouellette, M. \& Bergeron, M.G., 1999, 'Development of a PCR assay for rapid detection of enterococci', Journal of Clinical Microbiology 37(11), 3497-3503, viewed 01 June 2018, from http://www. ncbi.nlm.nih.gov/pubmed/10523541\%5Cnhttp://www.ncbi.nlm.nih.gov/pmc/ articles/PMC85677/pdf/jm003497.pdf

Kwon, K.H., Hwang, S.Y., Moon, B.Y., Park, Y.K., Shin, S., Hwang, C.-Y. \& Park, Y.H., 2012 'Occurrence of antimicrobial resistance and virulence genes, and distribution of enterococcal clonal complex 17 from animals and human beings in Korea' Journal of Veterinary Diagnostic Investigation 24(5), 924-931. https://doi.org/ $10.1177 / 1040638712455634$

Lebreton, F., Willems, R.J.L. \& Gilmore, M.S., 2014, 'Enterococcus diversity, origins in nature and gut colonization', in M. Gilmore, D. Clewell, Y. Ike \& N. Shankar (eds.), Enterococci: From commensals to leading causes of drug resistant infection, Massachusetts Eye and Ear Infirmary, Boston, viewed from https://www.ncbi.nlm. nih.gov/books/NBK190427/

Li, X., Xing, J., Li, B., Wang, P. \& Liu, J., 2012, 'Use of tuf as a target for sequence-based identification of Gram-positive cocci of the genus Enterococcus, Streptococcus, coagulase-negative Staphylococcus, and Lactococcus', Annals of Clinical Microbiology and Antimicrobials 11, 31. https://doi.org/10.1186/1476-0711-11-31

Lindenstrauß, A.G., Pavlovic, M., Bringmann, A., Behr, J., Ehrmann, M.A. \& Vogel, R.F., 2011, 'Comparison of genotypic and phenotypic cluster analyses of virulence determinants and possible role of CRISPR elements towards their incidence in Enterococcus faecalis and Enterococcus faecium', Systematic and Applied Microbiology 34(8), 553-560. https://doi.org/10.1016/j.syapm.2011.05.002

Liu, Y., Liu, K., Lai, J., Wu, C., Shen, J. \& Wang, Y., 2012, 'Prevalence and antimicrobial resistance of Enterococcus species of food animal origin from Beijing and Shandong Province, China', Journal of Applied Microbiology 114(2), 555-563. https://doi.org/10.1111/jam.12054

Molale, L.G. \& Bezuidenhout, C.C., 2016, 'Antibiotic resistance, efflux pump genes and virulence determinants in Enterococcus spp. from surface water systems', Environmental Science and Pollution Research International 23(21), 21501-21510. https://doi.org/10.1007/s11356-016-7369-7

Moraes, P.M., Perin, L.M., Todorov, S.D., Silva, A., Franco, B.D.G.M. \& Nero, L.A., 2012 'Bacteriocinogenic and virulence potential of Enterococcus isolates obtained from raw milk and cheese', Journal of Applied Microbiology 113(2), 318-328. https:// doi.org/10.1111/j.1365-2672.2012.05341.x
Ngbede, E.O., Raji, M.A., Kwanashie, C.N. \& Kwaga, J.K.P., 2017, 'Antimicrobial resistance and virulence profile of enterococci isolated from poultry and cattle sources in Nigeria', Tropical Animal Health and Production, 49(3), 451-458. sources in Nigeria', Tropical Animal Health
https://doi.org/10.1007/s11250-016-1212-5

Nilsson, O., 2012, 'Vancomycin resistant enterococci in farm animals - occurrence and importance', Infection Ecology \& Epidemiology 2, 1, 16959. https://doi. org/10.3402/iee.v2i0.16959

Ossiprandi, M.A. \& Zerbini, I., 2015, 'Antimicrobial susceptibility of Enterococcal species isolated from Italian Dogs', in M.C Ossiprandi (eds.), Antimicrobial resistance - An open challenge, InTech, viewed 01 June 2018, from https://www.intechopen.com/ books/antimicrobial-resistance-an-open-challenge/antimicrobial-susceptibility-ofenterococcal-species-isolated-from-italian-dogs

Potempa, A.J. \& Pike, R.N., 2009, 'Corruption of innate immunity by bacterial proteases', Journal of Innate Immunity 1(2), 70-87. https://doi.org/10.1159/ 000181144

Poyart, C., Quesnes, G. \& Trieu-cuot, P., 2000, 'Sequencing the gene encoding manganese-dependent superoxide dismutase for rapid species identification of enterococci sequencing the gene encoding manganese-dependent superoxide dismutase for rapid species identification of enterococci', Journal of Clinical dismutase for rapid species
Microbiology $38(1), 415-418$

Ruiz-barba, J.L., Maldonado, A. \& Jiménez-díaz, R., 2005, 'Small-scale total DNA extraction from bacteria and yeasts for PCR application', Analytical Biochemistry 347(2), 333-335. https://doi.org/10.1016/j.ab.2005.09.028

Said, L., Ben, D.R., Sassi, N., Lozano, C., Slama, K.B., Ouzari, I. et al., 2017, 'Species distribution, antibiotic resistance and virulence traits in enterococci from meat in Tunisia', Acta Veterinaria Hungarica 65(2), 179-184. https://doi.org/10.1556/ 004.2017.018

Santagati, M., Campanile, F. \& Stefani, S., 2012, 'Genomic diversification of enterococci in hosts: The role of the mobilome', Frontiers in Microbiology 3, 1-9. https://doi. org/10.3389/fmicb.2012.00095

Scheb-Wetzel, M., Rohde, M., Bravo, A. \& Goldmann, O., 2014, 'New insights into the antimicrobial effect of mast cells against Enterococcus faecalis', Infection and Immunity 82(11), 4496-4507. https://doi.org/10.1128/IAI.02114-14

Ŝeputienė, V., Bogdaitè, A., Ružauskas, M. \& Sužiedèlienè, E., 2012, 'Antibiotic resistance genes and virulence factors in Enterococcus faecium and Enterococcus faecalis from diseased farm animals: Pigs, cattle and poultry', Polish Journa of Veterinary Sciences 15(3), 431-438. https://doi.org/10.2478/v10181-0120067-6

Teixeira, L. \& Merquior, V.L., 2013, 'Molecular typing in bacterial infections', in I. Filippis \& M. McKee (eds.), Molecular typing in bacterial infections, Xii, vol. 1 pp. 17-27, Humana Press, New York. https://doi.org/10.1007/978-1-62703185-1

Ünal, N., Aşkar, Ş. \& Yildirim, M., 2017, 'Antibiotic resistance profile of Enterococcus faecium and Enterococcus faecalis isolated from broiler cloacal samples', Turkish Journal of Veterinary and Animal Sciences 41(2), 199-203. https://doi.org/ 10.3906/vet-1607-26

Upandhyaya, Pmg., Ravikumar, K. \& Umapathy, B., 2009, 'Review of virulence factors of Enterococcus: An emerging nosocomial pathogen', Indian Journal of Medical Microbiology 27(4), 301-305. https://doi.org/10.4103/0255-0857.55437

Waters, C.M., Antiporta, M.H., Murray, B.E. \& Dunny, G.M., 2003, 'Role of the Enterococcus faecalis Ge1E protease in determination of cellular chain length supernatant pheromone levels, and degradation of fibrin and misfolded surface proteins', Journal of Bacteriology 185(12), 3613-3623. https://doi.org/10.1128/ JB.185.12.3613-3623.2003

WHO, 2015, WHO's first ever global estimates of foodborne diseases find children under 5 accounts for almost one third of deaths, World Health Organization, viewed 13 September 2017, from http://www.who.int/mediacentre/news/releases/2015/ foodborne-disease-estimates/en/.

WHO, 2017, WHO / Zoonoses and the Human-Animal-Ecosystems Interface, Who.int. viewed 13 September 2017, from http://www.who.int/zoonoses/en/

Wurster, J.I., Saavedra, J.T. \& Gilmore, M.S., 2016, 'Impact of antibiotic use on the evolution of Enterococcus faecium', Journal of Infectious Diseases 213(12), 18621865. https://doi.org/10.1093/infdis/jiv598

Yildiz, O. \& Turkyilmaz, S., 2015, 'Investigation of Virulence Genes of Enterococcus faecalis strains isolated from mastitic bovine milk', Israel Journal of Veterinary Medicine 70(4), 15-21.

Yılmaz, E.Ş., Aslantaş, Ö., Önen, S.P., Türkyılmaz, S. \& Kürekci, C., 2016, 'Prevalence, antimicrobial resistance and virulence traits in enterococci from food of animal origin in Turkey', LWT - Food Science and Technology 66, 20-26. https://doi org/10.1016/j.Iwt.2015.10.009 